\title{
EFFECT OF AMAKUDARI ON BANK PERFORMANCE IN THE POST-BUBBLE PERIOD
}

\author{
by \\ Kenji Suzuki
}

Working Paper No. 136

November 2001 


\title{
Effect of Amakudari on Bank Performance in the Post-bubble period
}

\author{
KENJI SUZUKI \\ Stockholm School of Economics, Sweden \\ PO Box 6501, S111 40, Stockholm, Sweden \\ E-mail: Kenji.Suzuki@hhs.se
}

JEL CODES G21, G28

\section{ABSTRACT}

One of the curiosities about the Japanese banking sector for Westerners is the close connection between banks and the financial authority, namely Ministry of Finance (MoF). One of the important sources of this connection is the practice called amakudari. Amakudari symbolizes the practice under which retired government officials "descend from their heaven" to be employed in the private sector. The practice has long been carried out in the banking sector, as well as many other industrial sectors in Japan.

Previous studies, particularly Horiuchi and Shimizu (2001), examined the effect of the close connection between banks and the financial authority in Japan, so-called amakudari. However, their observation did not cover the "post-bubble" period in which one may expect some changes. The present study reexamines this amakudari practice adopting the latest data, redesigning and developing the previous model. It found that the overall effect of amakudari was reduced through the 1990s, but this is just because of the reduction of amakudari appointments. In fact, the gap between the banks with amakudari and the others became even wider in recent years.

Keywords amakudari, financial supervision, Japan, incentives of regulator, post-bubble

\section{Introduction}

One of the curiosities about the Japanese banking sector for Westerners is the close connection between banks and the financial authority, namely Ministry of Finance (MoF). One of the 
important sources of this connection is the practice called amakudari. Amakudari symbolizes the practice under which retired government officials "descend from heaven $(=$ the government)" to be employed in the private sector. The practice has long been carried out in the banking sector, as well as many other industrial sectors in Japan.

In the past, such connection was often considered useful to the development of Japanese banking sector as a means of supervision by the financial authority. The close human relationship made it easier for banks and public officials to communicate with each other. Moreover, many public officials viewed the amakudari employment as a compensation for their hard work when working for the ministry. According to the survey in 1994, seventy-six per cent of high-rank public officials believed that the amakudari system was necessary, and about one third of them mentioned their low salary as the reason for that (Nihon Keizai Shimbunsha, 1994).

Nevertheless, this way of supervision had been called into question since the collapse of the bubble economy in the early 1990s. Seven listed regional and second-tier regional banks failed in the 1990s, and all of them had employed amakudari executives during the bubble period (see Table 1). According to Hartcher, the amakudari practice "provided ministry policy makers with no notable insights into how bank lending was contributing to the accumulation of a large speculative bubble in land and stock prices" (1997: 121).

Table 1 Listed regional and second-tier regional banks that failed in the 1990s and the number of amakudari executives employed in 1990

\begin{tabular}{llc}
\hline Name & $\begin{array}{l}\text { Month and year } \\
\text { of failure }\end{array}$ & $\begin{array}{l}\text { Number of amakudari } \\
\text { executives in 1990 }\end{array}$ \\
\hline Hyogo Bank & August 1995 & 2 \\
Taiheiyo Bank & March 1996 & 0 \\
Hanwa Bank & November 1996 & 1 \\
Tokuyo City Bank & November 1997 & 3 \\
Tokyo Sowa Bank & June 1999 & 1 \\
Fukutoku Bank (Namihaya Bank from 1998) & August 1999 & 1 \\
Niigata Chuo Bank & October 1999 & 1 \\
\hline
\end{tabular}

It may be unjust to shift all responsibility to amakudari executives, because many banks without amakudari executives also contributed to the bubble economy and suffered from its collapse. Also, it is misleading to stress the incompetence of amakudari executives. They had no previous working experience in the banking sector, but that does not necessarily mean that 
they had "no notable insights". The recruitment of top executives from outside is not uncommon in the United States and elsewhere. It is just a prejudice that government officials are incompetent in the private sector.

Given the fact that all failed banks had employed amakudari executives, however, many observers suspect that the employment of amakudari gives rather negative effect on the performance of banks. Several studies have addressed this issue. For instance, Horiuchi and Shimizu (2000) conducted an empirical analysis and concluded that they found that banks with amakudari executives tend to be engaged in greater risk-taking than others. Van Rixtel and Hassink (1998) also drew a similar conclusion, particularly emphasizing the positive correlation between the employment of amakudari executives and the development of lending to risky industries, such as construction, real estate and financial sectors.

Nevertheless, both studies largely focused on the period before the collapse of the bubble economy. The data set of Horiuchi and Shimizu only counts the period up to 1991. Van Rixtel and Hassink dealt with several data sets, but none of them covered the period after 1993.

From the rise of the criticism against collusion between banks and MoF, and from relevant institutional changes for the supervision of banks in the post-bubble period, it may follow that the amakudari connection has made less effect, so that the gap between the performance of the banks with amakudari executives and that of the others became smaller.

However, the validity of this hypothesis should be tested with empirical analysis, and this is what the present study is aiming at. Regarding the scope of our analysis, we focus on regional and second-tier regional banks. There are several other types of bank in Japan (city banks, longterm credit banks, trust banks), but the amakudari practice is the most common among regional and second-tier regional banks. The second-tier regional banks were originally mutual loan and savings banks, but they were turned into ordinary commercial banks around 1990. Therefore, it is not necessary to differentiate the regional and second-tier regional banks, and the phrase "regional banks" is used here as a comprehensive term, instead of differentiating "regional banks" and "second-tier regional banks". Due to the availability of relevant data, this study only focuses on those regional banks listed in the Japanese stock exchange.

The rest of the paper is composed of four parts. The next section looks at the recent performance of regional banks as well as their amakudari practice as a whole. Section 3 discusses the models to see how the employment of amakudari executives affects the performance of banks, and shows the results of estimation. The discussion starts with the Horiuchi- Shimizu model, but we modify their model with other set of explanatory variables. Section 4 examines the time-persistence of the amakudari practice, also applying the model 
proposed by Horiuchi and Shimizu. It considers the change in the conditions where amakudari occurs. This leads to concluding remarks in the final section.

\section{The performance and amakudari employment of Japanese regional banks in the post-}

\section{bubble period}

There are eighty-two regional banks that were listed in the Japanese stock exchange and survived (i.e. not went bankruptcy nor merged with/ transferred into another bank) in the market up to the 1990s. Table 2 indicates the total asset, loan and deposit of those banks. As the bubble economy collapsed in 1992, the asset reduced by 2.4 per cent. However, the loan kept growing until 1998. The growth rate of the loan had exceeded that of the asset until 1997. The deposit showed larger growth than the asset and loan, except in 1992, 1995 and 1997. In 1999, the asset and loan indicated negative growth reflecting the prolonged economic slump, which particularly hit the main direction of loans from regional banks, i.e. small- and medium-sized firms. However, the growth rate of the deposit was positive even in that year. The stable growth of the deposit at the end of the 1990s corresponds to the growing propensity to savings among Japanese, many of whom were encouraged to save money to provide for their post-retirement under a precarious pension system.

Table 2 Total asset, loan and deposit of eighty-two regional banks: 1992-1999

\begin{tabular}{|c|c|c|c|c|c|c|}
\hline & \multicolumn{2}{|c|}{ Asset } & \multicolumn{2}{|l|}{ Loan } & \multicolumn{2}{|c|}{ Deposit } \\
\hline & (billion yen) & growth & (billion yen) & growth & (billion yen) & growth \\
\hline 1992 & 224,657 & $-2.4 \%$ & 151,727 & $3.0 \%$ & 194,039 & $0.6 \%$ \\
\hline 1993 & 227,492 & $1.3 \%$ & 153,828 & $1.4 \%$ & 196,947 & $1.5 \%$ \\
\hline 1994 & 229,843 & $1.0 \%$ & 156,173 & $1.5 \%$ & 201,526 & $2.3 \%$ \\
\hline 1995 & 233,824 & $1.7 \%$ & 161,717 & $3.6 \%$ & 203,375 & $0.9 \%$ \\
\hline 1996 & 234,209 & $0.2 \%$ & 162,188 & $0.3 \%$ & 204,412 & $0.5 \%$ \\
\hline 1997 & 233,476 & $-0.3 \%$ & 163,838 & $1.0 \%$ & 202,399 & $-1.0 \%$ \\
\hline 1998 & 237,028 & $1.5 \%$ & 165,395 & $1.0 \%$ & 206,633 & $2.1 \%$ \\
\hline 1999 & 233,051 & $-1.7 \%$ & 160,485 & $-3.0 \%$ & 209,045 & $1.2 \%$ \\
\hline 1992- & erage & $0.2 \%$ & & $1.1 \%$ & & $1.0 \%$ \\
\hline
\end{tabular}

Figure 1 shows the average capital/ asset ratio and the average profit/ asset ratio. The average capital/ asset ratio had been stagnant for several years after the collapse of the bubble economy. It underwent serious fall in 1997 due to the economic slump, but afterwards turned up quickly, probably because of the rise in the concern about risk management among the regional 
banks. The average current profit/ asset ratio was generally in the downturn through the postbubble period. It was even negative in 1997 and in 1998.

Figure 1 Average capital/ asset ratio and average current profit/ asset ratio: 1990-1999 (eighty-two regional banks)

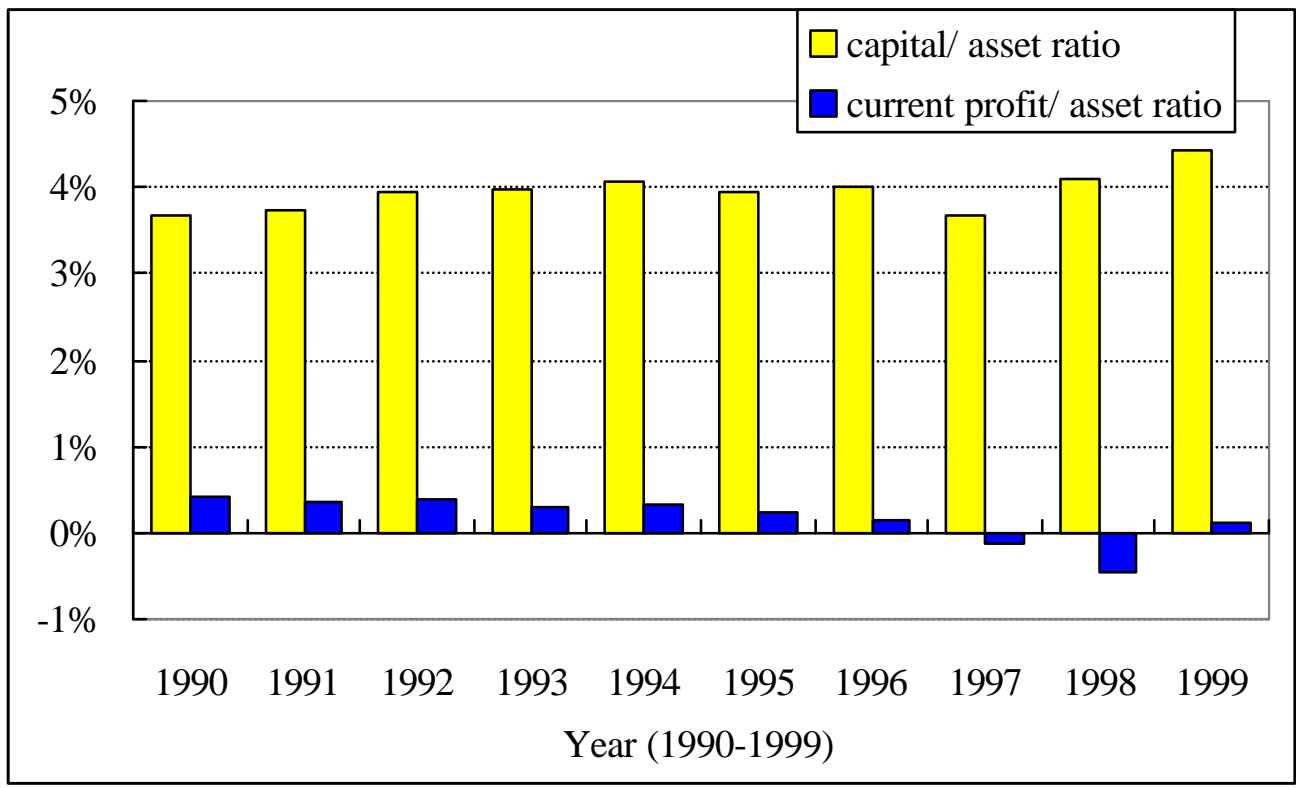

Figure 2 indicates the number of amakudari executives and the number of banks employing at least one amakudari executive. Both the number of amakudari executives and the number of banks employing amakudari executives steadily increased from 1992 to 1995, but turned into decline afterwards. The most plausible reason for this change is that the MoF was put under severe social criticism in 1995. Serious bribery scandals were found between the ministry officials and major banks. In the same year, the ministry was also put to blame for its failure of smooth management of bad loan problems regarding housing loan companies, as well as for mishandling of a criminal affair of Daiwa Securities in the United States. As a result, the number of amakudari executives reduced from fifty-seven in 1992 to forty-five in 1999. It should be noted, however, that the number of the banks employing amakudari did not decrease so much. The number of the banks employing amakudari is forty-two in 1992, and forty in 1999. What was decreased instead was the average number of amakudari executives per bank, as shown in Table 3. It was 1.36 in 1992 and 1.13 in 1999.

Regarding the number of retirements (from banks) and new appointments, fifty-two amakudari executives were retired and thirty-six appointments were newly made from 1992 to 1999. To divide the period into two parts, there were twenty-two retirements and thirty new 
appointments from 1992 to 1995, and thirty retirements and six new appointments from 1996 to 1999.

Figure 2 The number of amakudari executives in total and the number of banks with at least one amakudari executive: 1992-1999 (eighty-two banks)

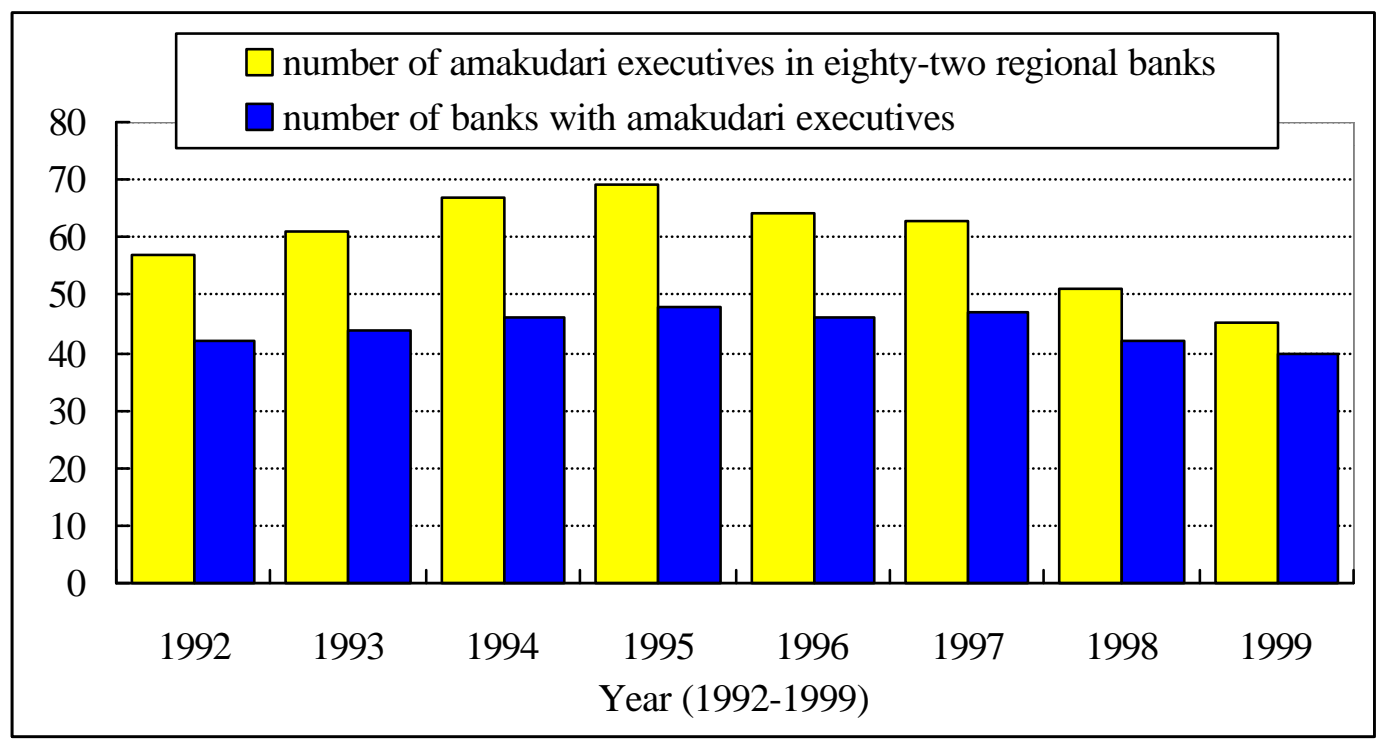

Table 3 Average number of amakudari executives per bank: 1992-1999

\begin{tabular}{|c|c|c|c|c|c|c|c|c|}
\hline Year & 1992 & 1993 & 1994 & 1995 & 1996 & 1997 & 1998 & 1999 \\
\hline $\begin{array}{c}\text { average number of amakudari } \\
\text { executives per bank }\end{array}$ & 1.36 & 1.39 & 1.46 & 1.44 & 1.39 & 1.34 & 1.21 & 1.13 \\
\hline
\end{tabular}

Traditionally, it was often the case that $\mathrm{MoF}$ arranged a new amakudari appointment to replace a retiring incumbent, so that the ministry could maintain a persistent control. With reference to the eighty-two regional banks in our data set, such replacement occurred in seven out of eighteen retirement cases from 1987 to 1991. Nevertheless, such replacements occurred in only five out of twenty-two retirement cases from 1992 to 1995. Furthermore, there was no such replacement from 1996 to 1999, even though twenty-nine incumbents retired during that period.

\section{The effect of theamakudari practice on the performance of banks}

\section{Methodology and data}

Horiuchi and Shimizu are among the first scholars to theorize and analyse the effect of the amakudari practice on the performance of regional banks. They formulate the relationship between taxpayers, banks and financial authority as the one between principal, agent and 
supervisor. They view the amakudari connection as the sign of the collusion between the agent (banks) and the supervisor (MoF), which benefit themselves at the cost of the principal (taxpayers). It is assumed that MoF allows banks with amakudari executives to expand more risk exposure than others, in return for banks' employing (hence paying good salaries to) amakudari executives. It is difficult for taxpayers to detect such collusion, if the regulating process is not transparent as had been the case in Japan at least before the amakudari practice was brought under severe public criticism.

Based on this theory, they utilized the following dynamic panel data model in order to examine the hypothesis that banks with amakudari executives tend to take more risk:

$$
\mathrm{EQT}_{\mathrm{i}}(\mathrm{t})=\mathrm{b}_{0}+\mathrm{b}_{1} \mathrm{EQT}_{\mathrm{i}}(\mathrm{t}-1)+\mathrm{b}_{2} \mathrm{GAS}_{\mathrm{i}}(\mathrm{t}-1)+\mathrm{b}_{3} \mathrm{PRO}_{\mathrm{i}}(\mathrm{t}-1)+\mathrm{b}_{4} \mathrm{AM}_{\mathrm{i}}(\mathrm{t}-1)+\mathrm{u}_{\mathrm{i}}(\mathrm{t}) \text { for } \mathrm{i}=1, \ldots, \mathrm{n} \text {. }
$$

where $\mathrm{EQT}_{\mathrm{i}}(\mathrm{t})$ is the current capital/ asset ratio of bank $\mathrm{i}$ at year $\mathrm{t} ; \mathrm{AM}_{\mathrm{i}}(\mathrm{t})$ is a dummy variable set equal to one if bank $\mathrm{i}$ employs amakudari executives at year $\mathrm{t}$ (taking zero if otherwise); $\mathrm{GAS}_{\mathrm{i}}(\mathrm{t})$ is the annual growth rate of total asset at time; and $\mathrm{PRO}_{\mathrm{i}}(\mathrm{t})$ is current profit per total assets. The panel data consist of 123 regional banks from 1977 to 1991 . This panel data model is "dynamic" in the sense that the set of the explanatory variables includes capital/ asset ratio at the previous year, i.e. $\mathrm{EQT}_{\mathrm{i}}(\mathrm{t}-1)$. The dynamic panel data model is useful in integrating the previous state of the dependent variable, so that it clarifies the contribution of the other explanatory variables to the marginal change of the dependent variable at its given level.

The statistical method utilized for this model was the generalized method of moments (GMM), which is widely recognized as useful for the analysis of dynamic panel data models. While GMM has several different estimators, Horiuchi and Shimizu applied the one presented by Arrelano and Bond, which does not require the assumption of strict exogeneity of explanatory variables, hence being the most appropriate to their model ${ }^{1}$.

The results of the Horiuch and Shimizu model are shown in Table 4. According to this, $\mathrm{EQT}_{\mathrm{i}}(\mathrm{t}-1)$ and $\mathrm{GAS}_{\mathrm{i}}(\mathrm{t}-1)$ are positive at the $1 \%$ level; $\mathrm{PRO}_{\mathrm{i}}(\mathrm{t}-1)$ is negative at the $1 \%$ level; and $\mathrm{AM}_{\mathrm{i}}(\mathrm{t}-1)$ is negative at the $10 \%$ level. The negative contribution of $\mathrm{AM}_{\mathrm{i}}(\mathrm{t}-1)$ to $\mathrm{EQT}_{\mathrm{i}}(\mathrm{t})$, which implies that banks tend to have low capital/ asset ratio if they employ amakudari executives in the previous year, is consistent with their hypothesis.

\footnotetext{
${ }^{1}$ See Arrelano and Bond (1991) for the explanation of their GMM estimation. Horiuch and Shimizu also give a concise explanation.
} 
Table 4 The effect of amakudari on the capital/ asset ratio of the Japanese regional banks: the results of GMM estimation, dependent variable: $\mathrm{EQT}_{\mathrm{i}}(\mathrm{t})$, period: 1979-1991 (123 banks)

\begin{tabular}{lc}
\hline Independent variables & Estimates (t-statistics) \\
\hline EQT $_{\mathrm{i}}(\mathrm{t}-1)$ & $0.549(8.421)^{* * * * *}$ \\
$\mathrm{GAS}_{\mathrm{i}}(\mathrm{t}-1)$ & $0.004(10.861)^{* * * *}$ \\
$\mathrm{PRO}_{\mathrm{i}}(\mathrm{t}-1)$ & $-0.010(3.455)^{* * * *}$ \\
$\mathrm{AM}_{\mathrm{i}}(\mathrm{t}-1)$ & $-0.002(1.828)^{*}$ \\
Sargan test & 0.006 \\
Arellano-Bond $\mathrm{m} 2$ test & 0.083 \\
No. of observations & 1476 \\
\hline
\end{tabular}

Note: $* \mathrm{p}<.1, * * \mathrm{p}<.05, * * * \mathrm{p}<.01$

Source: Horiuchi and Shimizu (2000)

Nevertheless, several questions can be posed to the selection of explanatory variables for this model. First, it is difficult to understand why the authors used the employment of amakudari executives at the previous year, $\mathrm{AM}_{\mathrm{i}}(\mathrm{t}-1)$, but not at the current year, $\mathrm{AM}_{\mathrm{i}}(\mathrm{t})$, as an explanatory variable. It would be more natural to assume that the current employment of amakudari executives should have an impact on the current capital/ asset ratio.

Secondly, the significance of the asset growth at the previous year, $\operatorname{GAS}_{\mathrm{i}}(\mathrm{t}-1)$, to the capital/ asset ratio at the current year, $\mathrm{EQT}_{\mathrm{i}}(\mathrm{t})$, is not evident. Banks may be encouraged to increase their capital when their asset grows, but they are not necessarily encouraged to increase their capital/ asset ratio as well.

Thirdly, the contribution of the profit/ asset ratio at the previous year, $\operatorname{PRO}_{\mathrm{i}}(\mathrm{t}-1)$, to the capital/ asset ratio at the current year, $\operatorname{EQT}_{i}(t)$, is not clear, either. It might be the case that profitable banks tend to reserve more capital, and thus has higher capital/ asset ratio. Yet the annual profit of banks is rarely stable reflecting volatile economic situations. Even if a bank earned much profit at the previous year and planned to increase its capital at the current year, it may well change that plan when its profit at the current year is very small. On top of that, it is difficult to understand why the contribution of $\mathrm{PRO}_{\mathrm{i}}(\mathrm{t}-1)$ was negative. For the relationship between profit and capital, instead, it would be better to assume the positive correlation between the current profit, $\mathrm{PRO}_{\mathrm{i}}(\mathrm{t})$, and the current capital/ asset ratio, $\mathrm{EQT}_{\mathrm{i}}(\mathrm{t})$, for more profit allows banks to reserve more capital. 
In short, even if the above model indicated statistically significant relationships between the above explanatory variables and the dependent variable $\mathrm{EQT}_{\mathrm{i}}(\mathrm{t})$, their causality remains unclear and underexplained.

In light of this, we modify the above model as follows. First, $\mathrm{AM}_{\mathrm{i}}(\mathrm{t}-1)$ and $\mathrm{PRO}_{\mathrm{i}}(\mathrm{t}-1)$ is replaced with $\mathrm{AM}_{\mathrm{i}}(\mathrm{t})$ and $\mathrm{PRO}_{\mathrm{i}}(\mathrm{t})$ respectively. Second, $\mathrm{GAS}_{\mathrm{i}}(\mathrm{t}-1)$ is removed. Instead, the loan/ asset ratio, $\mathrm{LON}_{\mathrm{i}}(\mathrm{t})$, and the deposit/ asset ratio, $\mathrm{DEP}_{\mathrm{i}}(\mathrm{t})$, are included as the risk indicators. When the loan/ asset ratio rises a sound bank may increase the capital/ asset ratio to prepare for a growing risk. Likewise, the fall of the deposit/ asset ratio may encourage banks to increase their capital ratio, partly because it indicates the reduction of the funds available to them, and partly because it may signal the fall of their social credit.

Hence a positive correlation is expected between $E Q T_{i}(t)$ and $\operatorname{LON}_{i}(t)$, and a negative correlation between $\mathrm{EQT}_{\mathrm{i}}(\mathrm{t})$ and $\mathrm{DEP}_{\mathrm{i}}(\mathrm{t})$. To summarize, our model is described as:

$$
E Q T_{i}(t)=b_{0}+b_{1} E Q T_{i}(t-1)+b_{2} L N_{i}(t)+b_{3} D E P P_{i}(t)+b_{4} P O_{i}(t)+b_{5} A M_{i}(t)+u_{i}(t) \text { for } i=1, \ldots, n .
$$

Our expectation from this model is that $b_{1}, b_{2}$ and $b_{4}$ are positive, and that $b_{3}$ is negative. For $\mathrm{b}_{5}$, it will be negative if the amakudari connection still functions as a means of collusion between the financial authority and banks.

The observation period is from 1992 to 1999 , since this study focuses on the period after the collapse of the bubble economy, and since the latest data available at the time of writing is of 1999. However, the data set includes the data from 1990 to 1991 as well, for the Arellano-Bond GMM estimation requires as instruments the data at least two years previous to the observation period. The summary statistics of the data in the period from 1990 to 1999 are presented in Appendix.

\section{Results}

Table 5 shows the result of the GMM estimation with the models (1) and (2) using the data of the 1990s in the left and centre columns respectively. Since two explanatory variables, the loan/ asset ratio, $\mathrm{LON}_{\mathrm{i}}(\mathrm{t})$, and the amakudari connection, $\mathrm{AM}_{\mathrm{i}}(\mathrm{t})$, turn out to be statistically insignificant in the model (2), the variable $\operatorname{LON}_{\mathrm{i}}(\mathrm{t})$ is removed according to the backward variable selection (F-threshold is 2.0). The insignificance of $\mathrm{LON}_{\mathrm{i}}(\mathrm{t})$ is understandable, given that the amount of loan on the whole is not an adequate indicator of risk. There are safe loans as well as risky loans, and the reaction of banks should vary from one loan to another. The model without $\mathrm{LON}_{\mathrm{i}}(\mathrm{t})$, which we call model (2)', produces the estimates shown in the left column. 
The Sargan test statistics and the Arellano-Bond m2 test statistics show that all models are neither over-identified nor serially correlated, so that they are considered as statistically robust.

The estimates with the model (1) are largely consistent with the results of the HoriuchiShimizu model in Table 4, despite the differences in the coverage of the data (Horiuchi and Shimizu included non-listed banks as well as listed banks) and the period. The coefficients of $\mathrm{EQT}_{\mathrm{i}}(\mathrm{t}-1)$ and $\mathrm{GAS}_{\mathrm{i}}(\mathrm{t}-1)$ are similarly positive and those of $\mathrm{PRO}_{\mathrm{i}}(\mathrm{t}-1)$ and $\mathrm{AM}_{\mathrm{i}}(\mathrm{t}-1)$ are similarly negative, although they and their t-statistics are not identical. This may suggest that the negative effect of the amakudari practice, argued by Horiuchi and Shimizu for the period between 1979 and 1991, still existed after 1992.

Table 5 The effect of amakudari on the capital/ asset ratio of the Japanese regional banks: the results of GMM estimation, dependent variable: $\mathrm{EQT}_{\mathrm{i}}(\mathrm{t})$, period: 1992-1999 (eighty-two banks)

\begin{tabular}{lccc}
\hline Independent variables & \multicolumn{3}{c}{ Estimates (t-statistics) } \\
& $0.457(4.311)^{* * * *}$ & $(2)$ & $(2)^{\prime}$ \\
\hline EQT $_{\mathrm{i}}(\mathrm{t}-1)$ & $0.012(1.737)^{*}$ & $0.227(2.545)^{* * * *}$ & $0.274(3.091)^{* * * *}$ \\
$\mathrm{GAS}_{\mathrm{i}}(\mathrm{t}-1)$ & $-0.338(3.894)^{* * * *}$ & & \\
$\mathrm{PRO}_{\mathrm{i}}(\mathrm{t}-1)$ & $-0.007(1.952)^{*}$ & & \\
$\mathrm{AM}_{\mathrm{i}}(\mathrm{t}-1)$ & & $0.016(0.577)$ & \\
$\mathrm{LON}_{\mathrm{i}}(\mathrm{t})$ & & $-0.051(1.930)^{*}$ & $-0.060(2.999)^{* * * *}$ \\
$\mathrm{DEP}_{\mathrm{i}}(\mathrm{t})$ & & $0.546(9.408)^{* * * *}$ & $0.645(10.658)^{* * * *}$ \\
$\mathrm{PRO}_{\mathrm{i}}(\mathrm{t})$ & & $-0.003(1.064)$ & $-0.003(1.929)^{*}$ \\
$\mathrm{AM}_{\mathrm{i}}(\mathrm{t})$ & & 27.753 & 33.265 \\
Sargan test & 31.063 & 0.435 & 0.395 \\
Arellano-Bond m2 test & -1.109 & 656 & 656 \\
No. of observations & 656 &
\end{tabular}

Note: t-statistics shown in parenthesis. ${ }^{*} \mathrm{p}<.1,{ }^{*} \mathrm{p}<.05, * * * \mathrm{p}<.01$

The negative effect of the amakudari practice are also confirmed by the model (2)', where the coefficient of $\mathrm{AM}_{\mathrm{i}}(\mathrm{t})$ is negative and statistically significant at $10 \%$ level. The other variables are also significant, and the previous capital/ asset ratio, $\mathrm{EQT}_{\mathrm{i}}(\mathrm{t}-1)$, and the current profit/ asset ratio, $\mathrm{PRO}_{\mathrm{i}}(\mathrm{t})$, make positive contribution, and the deposit/ asset ratio, $\mathrm{DEP}_{\mathrm{i}}(\mathrm{t})$, makes negative contribution, as expected beforehand.

On this point, it should be remembered that our data set does not include those banks which failed during the 1990s. Since all those banks employed one or more amakudari executives until the 1980s, the negative correlation between $\mathrm{EQT}_{\mathrm{i}}(\mathrm{t})$ and $\mathrm{AM}_{\mathrm{i}}(\mathrm{t})$ would be even clearer if they 
were included. Conversely, we may reject such an argument that the estimation of Horiuchi and Shimizu were biased due to some exceptionally bad banks. We have now obtained similar results from the data even without the failed banks.

\section{Further models and analyses}

To estimate the effect of the amakudari practice, neither the Horiuchi-Shimizu model nor the Van Rixtel-Hassink model takes consideration of any more than the presence of the employment of amakudari executives. Nevertheless, the pattern of the amakudari employment is far from identical. Appointment is made either to the presidential position or other less significant positions. The number of amakudari executives also varies from one bank to another. It may be reasonable to hypothesize that those differences should give different effect on the performance of banks. In order to verify this hypothesis, the model (2)' is modified in two ways. First, the dummy variable of the employment of amakudari executives, $\mathrm{AM}_{\mathrm{i}}(\mathrm{t})$, is replaced with two dummy variables, $\operatorname{AMP}_{i}(t)$ and $\operatorname{AMNP}_{i}(t) . \operatorname{AMP}_{i}(t)$ and $\operatorname{AMNP}_{i}(t)$ denote the employment of amakudari executives in the presidential position and in other positions, respectively. When a bank employs two or more amakudari executives, $\mathrm{AMP}_{\mathrm{i}}(\mathrm{t})$ equals one (and $\operatorname{AMNP}_{i}(t)$ equals zero) if one of them takes the presidential position. Second, $\operatorname{AM}_{\mathrm{i}}(\mathrm{t})$, is replaced with $\mathrm{AMN}_{\mathrm{i}}(\mathrm{t})$, the variable which represents the number of amakudari executives. The results are shown in Table 6 and 7.

From the results in Table 6, it follows that the employment of amakudari executives in the presidential position causes more negative effect than other cases. According to Table 7, moreover, the number of amakudari executives seems to be a significant variable, whose explanatory power is rather more robust than the dummy variable of amakudari employment. It is noteworthy that the number of amakudari variable has larger significance than the dummy variable for amakudari employment in the model (2)'. Given this result, it may be said that the amakudari practice has reduced its effect on the whole, as the number of amakudari executives decreased since 1996, as shown in Figure 2.

Table 6 The effect of the amakudari employment in the presidential and non-presitential positions on the capital/ asset ratio of the Japanese regional banks: the results of 
GMM estimation, dependent variable: $\mathrm{EQT}_{\mathrm{i}}(\mathrm{t})$, period: 1992-1999 (eighty-two banks)

\begin{tabular}{lc}
\hline Independent variables & Estimates \\
\hline $\mathrm{EQT}_{\mathrm{i}}(\mathrm{t}-1)$ & $0.270(3.059)^{* * * *}$ \\
$\mathrm{DEP}_{\mathrm{i}}(\mathrm{t})$ & $-0.060(3.018)^{* * * *}$ \\
$\mathrm{PRO}_{\mathrm{i}}(\mathrm{t})$ & $0.673(10.418)^{* * *}$ \\
$\mathrm{AMP}_{\mathrm{i}}(\mathrm{t})$ & $-0.005(1.750)^{*}$ \\
$\mathrm{AMNP}_{\mathrm{i}}(\mathrm{t})$ & $-0.003(1.487)$ \\
Sargan test & 32.631 \\
Arellano-Bond $\mathrm{m} 2$ test & 0.391 \\
No. of observations & 656 \\
\hline
\end{tabular}

Note: t-statistics shown in parenthesis. ${ }^{*} \mathrm{p}<.1,{ }^{* *} \mathrm{p}<.05, * * * \mathrm{p}<.01$

Table 7 The effect of the number of amakudari executives on the capital/ asset ratio of the Japanese regional banks: the results of GMM estimation, dependent variable: $\mathrm{EQT}_{\mathrm{i}}(\mathrm{t})$, period: 1992-1999 (eighty-two banks)

\begin{tabular}{lc}
\hline Independent variables & Estimates (t-statistics) \\
\hline $\mathrm{EQT}_{\mathrm{i}}(\mathrm{t}-1)$ & $0.308(3.182)^{* * * * *}$ \\
$\mathrm{DEP}_{\mathrm{i}}(\mathrm{t})$ & $-0.089(3.142)^{* * * *}$ \\
$\mathrm{PRO}_{\mathrm{i}}(\mathrm{t})$ & $0.616(8.765)^{* * * *}$ \\
$\mathrm{AMN}_{\mathrm{i}}(\mathrm{t})$ & $-0.003(2.475)^{* *}$ \\
Sargan test & 23.071 \\
Arellano-Bond $\mathrm{m} 2$ test & -0.369 \\
No. of observations & 656 \\
\hline
\end{tabular}

Note: $\mathrm{t}$-statistics shown in parenthesis. $* \mathrm{p}<.1, * * \mathrm{p}<.05, * * * \mathrm{p}<.01$

However, this does not mean that the effect of the amakudari practice in each case has reduced as well. Of course, it is not surprising that the effect has been diminished because of such changes as the rise of public concern about amakudari and the restructuring of the supervision of banks in the late 1990s. The new agency for the financial supervision, the Financial Supervisory Agency, was organizationally independent of MoF, hence the influence of amakudari executives on the supervising operation may well have diminished. To see the change over time, another model is formulated by distinguishing the effect of amakudari in the earlier period (1992-5) and in the later period (1996-9). Therefore, the model (2)' is modified as follows: 


$$
\begin{array}{r}
\operatorname{EQT}_{i}(t)=b_{0}+b_{1} E T_{i}(t-1)+b_{3} D E P_{i}(t)+b_{4} P R O_{i}(t)+A M 92-5_{i}(t)+A M 96-9_{i}(t)+u_{i}(t) \\
\text { for } i=1, \ldots, n
\end{array}
$$

AM92-5 $5_{\mathrm{i}}(\mathrm{t})$ and AM96-9 $9_{\mathrm{i}}(\mathrm{t})$ are time-related dummy variables for the employment of amakudari executives from 1992 to 1995 and from 1996 to 1999 respectively. The effect of the number of amakudari executives is also examined by using time-related variables, AMN92-5 $(\mathrm{t})$ and AMN96- $9_{\mathrm{i}}(\mathrm{t})$. The results are shown in Table 8. AM92-5 $(\mathrm{t})$ is marginally insignificant at the 10\% level, but AM96-9 $9_{i}(t)$ is negative at the 5\% level. AMN92-5 $(t)$ and AM96- $9_{i}(t)$ are negative at the $5 \%$ level and the $1 \%$ level respectively.

Table 8 The effect of amakudari on the capital/ asset ratio of the Japanese regional banks (time-related dummy variables): the results of GMM estimation, dependent variable: $\mathrm{EQT}_{\mathrm{i}}(\mathrm{t})$, period: 1992-1999 (eighty-two banks)

\begin{tabular}{lcc}
\hline Independent variables & \multicolumn{2}{c}{ Estimates (t-statistics) } \\
\hline EQT $_{\mathrm{i}}(\mathrm{t}-1)$ & $0.244(5.734)^{* * * *}$ & $0.253(2.688)^{* * * *}$ \\
$\mathrm{DEP}_{\mathrm{i}}(\mathrm{t})$ & $-0.074(3.438)^{* * * *}$ & $-0.087(2.905)^{* * *}$ \\
PRO $_{\mathrm{i}}(\mathrm{t})$ & $0.596(8.960)^{* * * *}$ & $0.564(7.778)^{* * *}$ \\
$\mathrm{AM}^{*}-5_{\mathrm{i}}(\mathrm{t})$ & $-0.003(-1.616)$ & \\
$\mathrm{AM} 96-9 \mathrm{i}(\mathrm{t})$ & $-0.004(2.211)^{* *}$ & \\
$\mathrm{AMN92-5}_{\mathrm{i}}(\mathrm{t})$ & & $-0.003(1.964)^{* *}$ \\
AMN96-9 $_{\mathrm{i}}(\mathrm{t})$ & & $-0.004(2.787)^{* * * *}$ \\
Sargan test & 31.084 & 19.287 \\
Arellano-Bond m2 test & 0.098 & -0.267 \\
No. of observations & 656 & 656 \\
\hline
\end{tabular}

Note: t-statistics shown in parenthesis. ${ }^{*} \mathrm{p}<.1,{ }^{* *} \mathrm{p}<.05, * * * \mathrm{p}<.01$

The results imply that the negative effect of amakudari, in terms of both employment and number, is greater and more significant in the second period than in the first period. In other words, the difference between amakudari banks and non-amakudari banks became even more salient in the later period. This may sound strange. Given the changes stated above, it may be more natural to expect that the negative effect of amakudari should get smaller as time goes on.

One possible interpretation of the results is that the appointment of amakudari became more selective in the later period, so that amakudari executives were appointed to only very unhealthy banks. Another interpretation may be that non-amakudari banks were quicker to react to the social criticism and the new type of supervision than amakudari banks. The results may reflect both. 
Finally, let us examine the effect of amakudari from the Bank of Japan (BoJ). Following the Horiuchi-Shimizu model, the above models only take account of amakudari from MoF. Indeed, Horiuchi and Shimizu rejected the effect of amakudari from BoJ. According to them, BoJ amakudari does not affect the performance of banks because $\mathrm{BoJ}$ does not have an authority to supervise the management of banks directly, even though it plays a role of providing special loans for banks in trouble.

In their study, however, they did not utilize the GMM estimation to examine this hypothesis, for unknown reasons. Meanwhile, Van Rixtel and Hassink treated amakudari from MoF and BoJ equally, without any specific discussion. Therefore, it is meaningful to estimate the effect of $\mathrm{BoJ}$ amakudari in our study. Then $\mathrm{AM}_{\mathrm{i}}(\mathrm{t})$ in the model (2)' is again replaced with $\mathrm{AMB}_{\mathrm{i}}(\mathrm{t})$ and $\mathrm{AMNB}_{\mathrm{i}}(\mathrm{t})$, which represent the employment and the number of amakudari executives from BoJ respectively. The result is that neither $\operatorname{AMB}_{i}(t)$ nor $\operatorname{AMNB}_{i}(t)$ is statistically significant, as shown in Table 9. Even if they are significant, their coefficients are nearly equal to zero, so that the influence of BoJ amakudari is not observed at all. Therefore, we may conclude the argument of Horiuchi and Shimizu is acceptable.

Table 9 The effect of the employment and the number of BoJ amakudari executives on the capital/ asset ratio of the Japanese regional banks: the results of GMM estimation, dependent variable: $\mathrm{EQT}_{\mathrm{i}}(\mathrm{t})$, period: 1992-1999 (eighty-two banks)

\begin{tabular}{lcc}
\hline Independent variables & \multicolumn{2}{c}{ Estimates (t-statistics) } \\
\hline $\mathrm{EQT}_{\mathrm{i}}(\mathrm{t}-1)$ & $0.289(5.010)^{* * * *}$ & $0.295(4.993)^{* * * *}$ \\
$\mathrm{DEP}_{\mathrm{i}}(\mathrm{t})$ & $-0.050(3.309)^{* * * *}$ & $-0.048(3.081)^{* * *}$ \\
$\mathrm{PRO}_{\mathrm{i}}(\mathrm{t})$ & $0.657(11.604)^{* * * *}$ & $0.653(11.709)^{* * *}$ \\
$\mathrm{AMB}_{\mathrm{i}}(\mathrm{t})$ & $-0.000(0.387)$ & \\
$\mathrm{AMBN}_{\mathrm{i}}(\mathrm{t})$ & & $0.000(0.140)$ \\
Sargan test & 32.834 & 32.364 \\
Arellano-Bond m2 test & 0.714 & 0.744 \\
No. of observations & 656 & 656 \\
\hline
\end{tabular}

Note: t-statistics shown in parenthesis. ${ }^{*} \mathrm{p}<.1, * * \mathrm{p}<.05, * * * \mathrm{p}<.01$

\section{Conclusion}

This paper examines if, and how much, the amakudari connection affected the performance of banks in the post-bubble period. According to the general overview, the capital/ asset ratio, 
which is regarded as an indicator of the prudential behaviour of banks, had grown by the end of the 1990s. In other words, banks appears to have performed more prudently. With the dynamic panel data analysis of eighty-two regional banks, we also found that the employment of amakudari executives still had a negative impact on the bank performance. The impact seems to be larger when amakudari employees took the presidential position. The number of amakudari executives also seems to matter.

Since the number of amakudari executives was on the decline after 1996, the overall effect of the amakudari practice was reduced. It should be stressed, however, that the effect of individual amakudari employment on bank performance became rather more negative and more significant in more recent years. This is presumably because the appointment of amakudari became more selective and concentrated more on unhealthy banks, and because the banks without amakudari executives were more reactive to the changes in the external environment.

It should be remembered, however, that the scope of our data is rather limited. There are over thirty regional banks excluded from our data set. Their data were not properly available, either because they had failed and/ or merged with another bank, or because they were not listed in the stock exchange throughout the period. It should also be noted that this study covers an only very short period. It is reasonably expected that the effect of amakudari employment will be less significant in the future, because of the disengagement of the MoF from the financial supervision by the Financial Supervision Agency. Nonetheless, it is still too early to make a judgement on the effect of the new supervisory scheme. It should also be remembered that the government still largely maintains the personnel system where internal promotion is dominant for the higher-ranking positions, and where amakudari motivates younger officials to work hard until they reach the top position. Unless this traditional personnel system changes, the impulse for amakudari positions will not disappear. It is therefore necessary to keep our attention to that practice at least in the coming years, even though it no doubt becomes less significant.

Appendix Summary statistics of the data set 


\begin{tabular}{lcccc}
\hline Variable & Mean & $\begin{array}{c}\text { Standard } \\
\text { deviation }\end{array}$ & Maximum & Minimum \\
\hline EQT & 0.040 & 0.009 & 0.001 & 0.070 \\
GAS & 0.014 & 0.064 & -0.152 & 1.506 \\
PRO & 0.002 & 0.005 & -0.050 & 0.009 \\
LON & 0.685 & 0.063 & 0.449 & 0.850 \\
DEP & 0.876 & 0.035 & 0.717 & 1.036 \\
AMN & 0.737 & 0.814 & 0 & 4 \\
AMN92-5 & 0.465 & 0.759 & 0 & 4 \\
AMN96-9 & 0.272 & 0.583 & 0 & 4 \\
AMBN & 0.584 & 0.666 & 0 & 3 \\
\hline & & & & \\
& & & & \\
\hline Variable & Mean & Standard & Cases 0 & Cases 1 \\
\hline AM & 0.543 & 0.498 & 375 & 445 \\
AMP & 0.129 & 0.336 & 714 & 106 \\
AMNP & 0.413 & 0.493 & 481 & 339 \\
AM92-5 & 0.329 & 0.470 & 550 & 270 \\
AM96-9 & 0.213 & 0.410 & 645 & 175 \\
AMB & 0.489 & 0.500 & 419 & 401 \\
\hline
\end{tabular}

\section{Acknowledgement}

This study is a part of the project entitled "Comparative Analysis of Policy-making Process for the Restructuring of the Financial System after Bubble - cases of Japan and Nordic Countries". The author fully acknowledges the financial support of The Matsushita International Foundation for the project. The original version of this paper was presented at International Convention of Asian Studies in August 2001, and at the Annual Conference for Euro-Asia Management Studies Association in November 2001. The author is thankful for the comments from various readers and conference participants, particularly Professor Akiyoshi Horiuchi at University of Tokyo, Professor Magnus Blomström and Dr. Hiroshi Ono at Stockholm School of Economics, Professor Chung H. Lee at University of Hawaii, and Mr. Takuma Kiso at Fuji Research Institute Corporation.

\section{References}

Arrelano, Manuel and Bond, Stephen (1991) 'Some Tests of Specification for Panel Data: Monte Carlo Evidence and an Application to Employment Equations', Review of Economic Studies 58: 277-297.

Hartcher, Peter (1998) The Ministry: The Inside Story of Japan's Ministry of Finance, London: Harper Collins Business. 
Horiuchi, Akiyoshi and Shimizu, Katsutoshi (2000) 'Kinyu sisutemu no zeijakusei to amakudari (Vulnerability of the financial system and amakudari)', in Hirofumi Uzawa and Masaharu Hanazaki (eds) Kinyu sisutemu no keizaigaku (Economics of the financial system), Tokyo Daigaku Shuppankai: Tokyo, pp.83-111.

- (2001) 'Did amakudari undermine the effectiveness of regulator monitoring in Japan?', Journal of Banking \& Finance, Vol.25, Iss.3, pp.573-96.

Nihon Keizai Shimbunsha (ed.) (1994) Kanryo - Kishimu Kyodai Kenryoku (Bureaucrats Creaking Great Power), Tokyo, Nihon Keizai Shimbunsha.

Toyokeizai Shimposha, Kigyo Keiretsu Soran, various issues, Tokyo: Toyokeizai Shimposha

- Kaisha Shikiho, various issues, Tokyo: Toyokeizai Shimposha.

Van Rixtel, Adrian A. R. J. and Hassink, Wolter H. J. (1998) 'Monitoring the monitors: amakudari and the ex-post monitoring of private banks', Discussion Paper No. 1785, January 1998, London, Centre for Economic Policy Research. 